\title{
Production of Interleukin-6 by Fetal and Maternal Cells in Vivo during Intraamniotic Infection and in Vitro after Stimulation with Interleukin-1 ${ }^{1}$
}

\author{
KENNETH W. LIECHTY, JOYCE M. KOENIG, MURRAY D. MITCHELL, ROBERTO ROMERO, \\ AND ROBERT D. CHRISTENSEN \\ Division of Human Development and Aging, the Clinical Research Center, and the Division of Reproductive \\ Sciences, Department of Obstetrics and Gynecology, University of Utah School of Medicine, Salt Lake City, Utah \\ 84132 and the Department of Obstetrics and Gynecology. Yale University School of Medicine, New Haven, \\ Connecticut 06510
}

\begin{abstract}
Amniotic fluid samples were obtained by transabdominal amniocentesis from 20 women in preterm labor ( $\leq 34$ wk gestation). Concentrations of IL- 6 in culture-positive amniotic fluids (mean $8706 \mathrm{pg} / \mathrm{mL}$, range $5100-14446 \mathrm{pg} / \mathrm{mL}$ ) were higher than those in culturenegative fluids (mean $1133 \mathrm{pg} / \mathrm{mL}$, range $15-6534 \mathrm{pg} / \mathrm{mL}$, $p<0.0001$ ) or fluids from healthy term pregnancies (mean $196 \mathrm{pg} / \mathrm{mL}$, range $\leq 5-790 \mathrm{pg} / \mathrm{mL}, p<0.001$ ). To assess possible sources of the IL-6 in amniotic fluid, we tested the ability of a variety of fetal and maternal cells to produce IL-6 in vitro after stimulation with IL-1, a cytokine known to stimulate IL-6 production. Very low concentrations of IL-6 were present in supernatants of cells not stimulated with IL-1; however, high concentrations were observed in supernatants of stimulated umbilical venous endothelial cells, decidual cells, and fetal and maternal blood mononuclear cells. To determine whether cells from adults produce IL-6 with kinetics similar to those of neonates, we incubated mononuclear cells obtained from blood of adults and term and preterm neonates with IL-1. After 6 h, IL-6 was detected in supernatants of adult cells and term neonatal cells, but not in supernatants of preterm cells. Concentrations at 18, 24, and $48 \mathrm{~h}$ were similar for adult and term cell supernatants, but were lower in supernatants of preterm cells. We also observed considerably more IL-6 mRNA accumulation in circulating mononuclear cells from adults than in those from neonates. (Pediatr Res 29: 1-4, 1991)
\end{abstract}

Abbreviations

CSF, colony stimulating factor

Intraamniotic infection is one of the causes of preterm labor (1-5). Thus, in women with preterm labor, efforts are often made to establish whether or not intraamniotic infection is present $(4$, 5). Such information can influence the management of the

Received July 5, 1990; accepted September 6, 1990.

Correspondence: Robert D. Christensen, M.D., Division of Human Development and Aging, University of Utah, 50 North Medical Drive, Salt Lake City UT 84132 .

Supported by grants from the National Institutes of Health: HD-20830, HD20779, HD-20747, and RR-00064.

'Presented in part at the Annual Meeting of the Society for Pediatric Research, Anaheim, CA, May 1990. pregnancy. For instance, if infection is detected delivery is generally recommended, but if infection is not present tocolysis might be attempted $(4,5)$.

Despite its pivotal role in management, rapid diagnosis of intraamniotic infection in its early stages is often difficult. For instance, the time required to obtain results of amniotic fluid cultures severely limits the usefulness of this test in immediate management. Although Gram stains of amniotic fluid can be obtained promptly, they appear to be relatively insensitive indicators of early infection $(6,7)$. Additionally, clinical signs of infection, such as maternal fever, neutrophilia, a leukocyte "left shift" (8), fetal tachycardia, or the loss of beat-beat variability (9), might be relatively late-appearing (5). Thus, rapid tests that are sensitive and specific for the diagnosis of intraamniotic infection would be useful.

IL-6 is a multifunctional cytokine that appears to play a central role in antibacterial defense (10). Recognized functions of this 23 to $26-\mathrm{kDa}$ glycoprotein include stimulation of antigen-specific antibody production by B-cells (11), stimulation of T-cell proliferation and differentiation (12), and induction of hematopoietic progenitor cell cycling (13-16). Because of its role in antibacterial defense, we postulated that concentrations of IL-6 might be elevated in amniotic fluid if intraamniotic infection was present. To test this hypothesis, we obtained amniotic fluid by transabdominal amniocentesis from 20 women with the diagnosis of preterm labor ( $\leq 34$ wk gestation) and five women with healthy pregnancies at term and subjected the samples to culture and IL6 quantification. We observed that IL- 6 concentrations were elevated in specimens from which bacteria were cultured. To assess the possible sources of the IL- 6 in infected amniotic fluid, we tested the capacity of a variety of fetal and maternal cell types to produce IL- 6 in vitro. We also assessed the kinetics of IL-6 production and IL-6 mRNA accumulation in mononuclear cells obtained from blood of adults versus term and preterm neonates.

\section{MATERIALS AND METHODS}

Subjects. Amniotic fluid was obtained by transabdominal amniocentesis of 20 women admitted with the diagnosis of labor at $\leq 34$ wk gestation. Samples were also obtained at cesarean section delivery of five healthy term pregnancies. The amniotic fluid specimens were capped and transported immediately to the laboratory for culture and then stored at $-20^{\circ} \mathrm{C}$ until the IL- 6 concentrations were measured. Blood was obtained by venipuncture from 10 healthy adults and by needle-puncture of an umbilical vessel immediately after delivery of five noninfected term neonates and three noninfected preterm neonates (29-30 wk 
gestation). Blood mononuclear cells were obtained after density gradient centrifugation (sp gr $<1.077$ ) of heparinized blood (Squibb-Marsam, Inc., Cherry Hill, NJ). The cell types in the mononuclear preparations were assessed by $200-500$ differential cell counts on Wright stained smears.

Placentas were obtained from five women with normal pregnancies after cesarean section delivery, and decidual cells were isolated and cultured as previously described (17). Endothelial cells were obtained from umbilical cord veins of five normal pregnancies and cultured as described by Jaffe et al. (18). The studies were approved by the Institutional Review Boards of the University of Utah and Yale University, and informed consent was obtained from the participants.

Bacterial cultures. Aliquots of the 20 amniotic fluid samples were plated within $30 \mathrm{~min}$ of collection on blood agar, MacConkey agar, Columbia colistin-nalidixic acid agar, and chocolate agar $\left(36^{\circ} \mathrm{C}\right.$ in $\left.8 \% \mathrm{CO}_{2}\right)$ for aerobic culture, and blood agar, Bacteroides, bile-esculin agar/laked kanamycin, vancomycin agar, and Martin-Lewis agar (all prereduced) for anaerobic culture. Amniotic fluid was also inoculated in thioglycollate broth. For Mycoplasma and Ureaplasma cultures, amniotic fluid was centrifuged at $2000 \times g$ for $20 \mathrm{~min}$ and the sediment placed into $2 \mathrm{~mL}$ holding media (pleuropneumonia-like organism broth, supplemented with fresh yeast extract and horse serum, penicillin, polymixin B, and amphotericin).

Recombinant factors and conditioned media. Purified recombinant human IL-1 alpha (R\&D Systems, Minneapolis, MN) had a sp act of $\geq 5 \times 10^{8} \mathrm{U} / \mathrm{mg}$ with a purity by SDS-PAGE $\geq 95 \%$. Endothelial and decidual cell monolayers were incubated in $35-\mathrm{mm}$ tissue culture dishes for $16 \mathrm{~h}$ at $37^{\circ} \mathrm{C}$ and $5 \% \mathrm{CO}_{2}$,

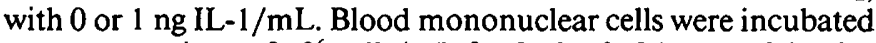
at concentrations of $10^{6}$ cells/mL for $2,6,18,24$, and $48 \mathrm{~h}$ with 0 or $1 \mathrm{mg} \mathrm{IL}-1 / \mathrm{mL}$. Concentrations of IL- 6 were assayed by ELISA (R\&D Systems). No cross-reactivity of the IL-6 ELISA with other cytokines (GM-CSF, G-CSF, M-CSF, IL-3, IL-2, IL4 , tumor necrosis factor, or erythropoietin) was observed, and the method was sensitive to concentrations as low as $5 \mathrm{pg} / \mathrm{mL}$.

RNA isolation. Blood mononuclear cells, at a concentration of $10^{6} / \mathrm{mL}$, were obtained from three adults, three term neonates, and three preterm neonates (29-30 wk gestation), and studied either before or $24 \mathrm{~h}$ after incubation with $1 \mathrm{ng}$ IL-1/mL. RNA was extracted using a guanidinium thiocyanate extraction buffer and isolated by centrifugation through a cesium chloride gradient (19). The RNA was then subjected to electrophoresis through a $1 \%$ agarose-formaldehyde gel and the RNA transferred to a Biotrace nylon membrane (Gelman Sciences, Ann Arbor, MI) (19). The RNA was immobilized on the membrane by UV crosslinking (20). The human IL-6 cDNA probe (pCSF309, American Type Culture Collection, Rockville, MD) was labeled, hybridized to the blot, washed, and subjected to autoradiography (19).

Statistical analyses. The $t$ test was used for assessing differences between groups.

\section{RESULTS}

Concentrations of IL-6 in amniotic fluid samples. Organisms were isolated from 10 of the amniotic fluid samples. The organisms recovered are listed in Table 1 . The gestational ages of the 10 pregnancies with culture-positive amniotic fluid $(26 \pm 3 \mathrm{wk}$ gestation; mean $\pm \mathrm{SD}$ ) were less than those of the 10 preterm pregnancies with culture-negative fluid $(31 \pm 4 \mathrm{wk}, p<0.001)$. All five healthy term pregnancies were $38-40 \mathrm{wk}$ gestation.

Concentrations of IL- 6 in each of the 25 amniotic fluid samples are shown in Figure 1. IL-6 concentrations in the five control samples ranged from $\leq 5-790 \mathrm{pg} / \mathrm{mL}$. The 10 culture-negative preterm samples ranged from 15 to $6534 \mathrm{pg} / \mathrm{mL}$. Considerably higher concentrations of IL- 6 were present in the culture-positive samples (mean $8706 \mathrm{pg} / \mathrm{mL}$, range $5100-14446 \mathrm{pg} / \mathrm{mL}, p<$ 0.0001 versus control and versus culture-negative).

Production of IL-6 by fetal and maternal cells. To assess IL-6
Table 1. Organisms isolated from amniotic fluid from 10 women with preterm labor

\begin{tabular}{lc}
\hline \multicolumn{1}{c}{ Organism* } & Number of patients \\
\hline Gardnerella vaginalis & 4 \\
Ureaplasma urealyticum & 2 \\
Fusobacterium sp. & 2 \\
Candida tropicalis & 1 \\
Mixed anaerobic flora & 1 \\
Clostridium sp. & 1 \\
Capnocytophaga sp. & 1 \\
\hline
\end{tabular}

* Twelve types of organisms were grown from the 10 samples; one sample grew both Capnocytophaga and Clostridium, another grew both Gardnerella vaginalis and Ureaplasma urealyticum.

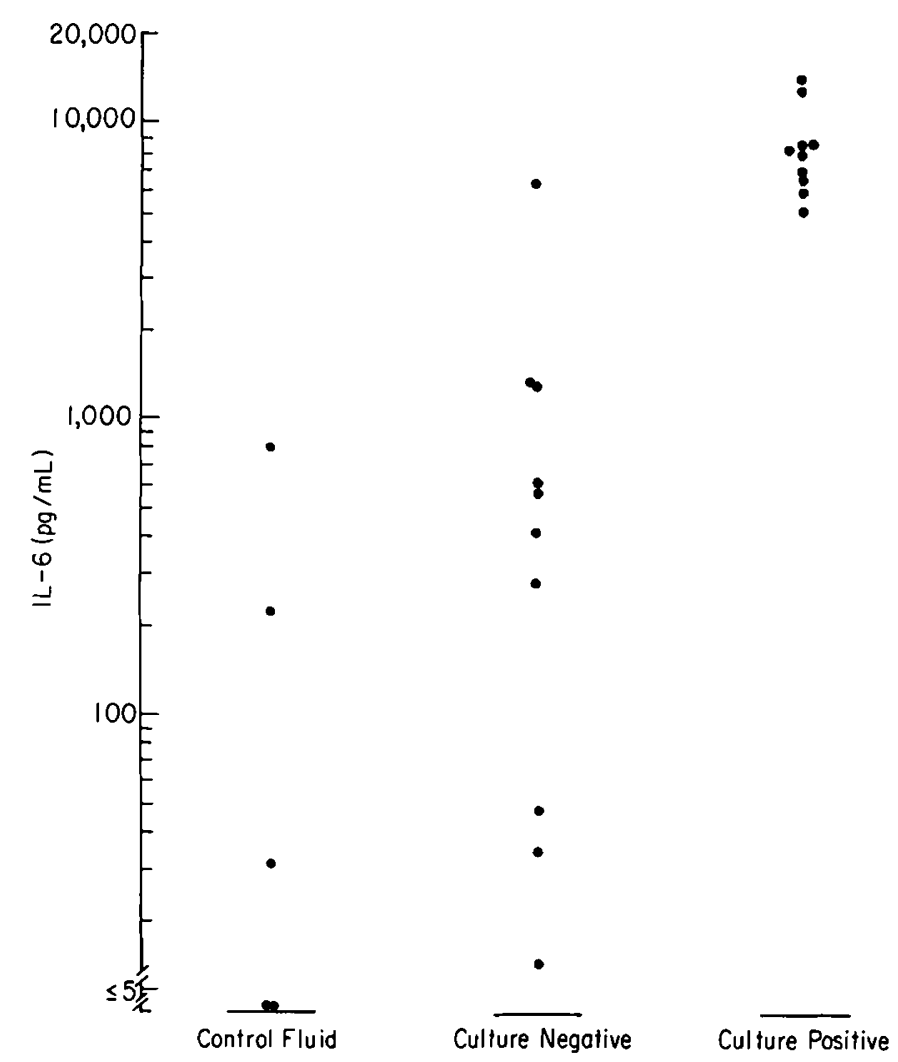

Fig. 1. Interleukin-6 concentrations were determined in amniotic fluid samples obtained from five healthy term pregnancies (Control Fluid) and compared with concentrations in 20 amniotic fluid samples obtained by transabdominal amniocentesis of women with the diagnosis of preterm labor ( $<34$ wk gestation). In 10 of the 20 samples, no organisms were cultured (Culture Negative) and, in the other 10, organisms were cultured (Cullure Positive). The IL-6 concentration in each of the samples is represented by a dot.

production by fetal and maternal cells, umbilical venous endothelium, blood mononuclear cells, and decidua were placed in liquid culture for 16-18 h, after which concentrations of IL-6 in the supernatants were measured. As shown in Table 2 , low or undetectable concentrations of IL- 6 were present in supernatants of cells to which IL-1 was not added. With the addition of IL-1, however, high concentrations of IL-6 were detected in supernatants of all of the cell types tested.

Kinetics of IL-6 production by blood mononuclear cells. Production of IL- 6 by mononuclear cells from the blood of adults and from term and preterm neonates is shown in Figure 2. After $2 \mathrm{~h}$ of culture, no samples had detectable IL- 6 concentrations $(\leq 5 \mathrm{pg} / \mathrm{mL})$. After $6 \mathrm{~h}$ of culture, however, IL-6 was detected in supernatants of adult $(61 \pm 23 \mathrm{pg} / \mathrm{mL}$, mean $\pm \mathrm{SEM})$ and term neonatal cells $(99 \pm 56 \mathrm{pg} / \mathrm{mL})$, but was not detected in supernatants of cells from preterm neonates. Concentrations of IL-6 
Table 2. IL-6 concentrations determined in supernatants 16-18 $h$ after stimulation with $I L-1$ of cells from term neonates (umbilical venous endothelium and mononuclear blood cells) or maternal cells (decidua and mononuclear blood cells)

\begin{tabular}{|c|c|c|c|c|}
\hline & \multicolumn{4}{|c|}{ IL-6 $(\mathrm{pg} / \mathrm{mL})^{*}$} \\
\hline & \multicolumn{2}{|c|}{ Term Neonatal Cells } & \multicolumn{2}{|c|}{ Adult cells } \\
\hline & $\begin{array}{l}\text { Umbilical } \\
\text { venous } \\
\text { endothelium }\end{array}$ & $\begin{array}{c}\text { Mononuclear } \\
\text { blood cells }\end{array}$ & Decidua & $\begin{array}{c}\text { Mononuclear } \\
\text { blood cells }\end{array}$ \\
\hline $\begin{array}{l}\text { Stimulated } \\
\text { Nonstimulated }\end{array}$ & $\begin{array}{c}6189 \pm 1691 \\
26 \pm 11\end{array}$ & $\begin{array}{c}3261 \pm 908 \\
\leq 5\end{array}$ & $\begin{array}{c}2960 \pm 884 \\
140 \pm 79\end{array}$ & $\begin{array}{c}4521 \pm 227 \\
63 \pm 58\end{array}$ \\
\hline
\end{tabular}

* Concentrations of IL- 6 in supernatants from control (nonstimulated) cells were also determined. Each value represents the mean $( \pm S D)$ of five samples, each run in duplicate.

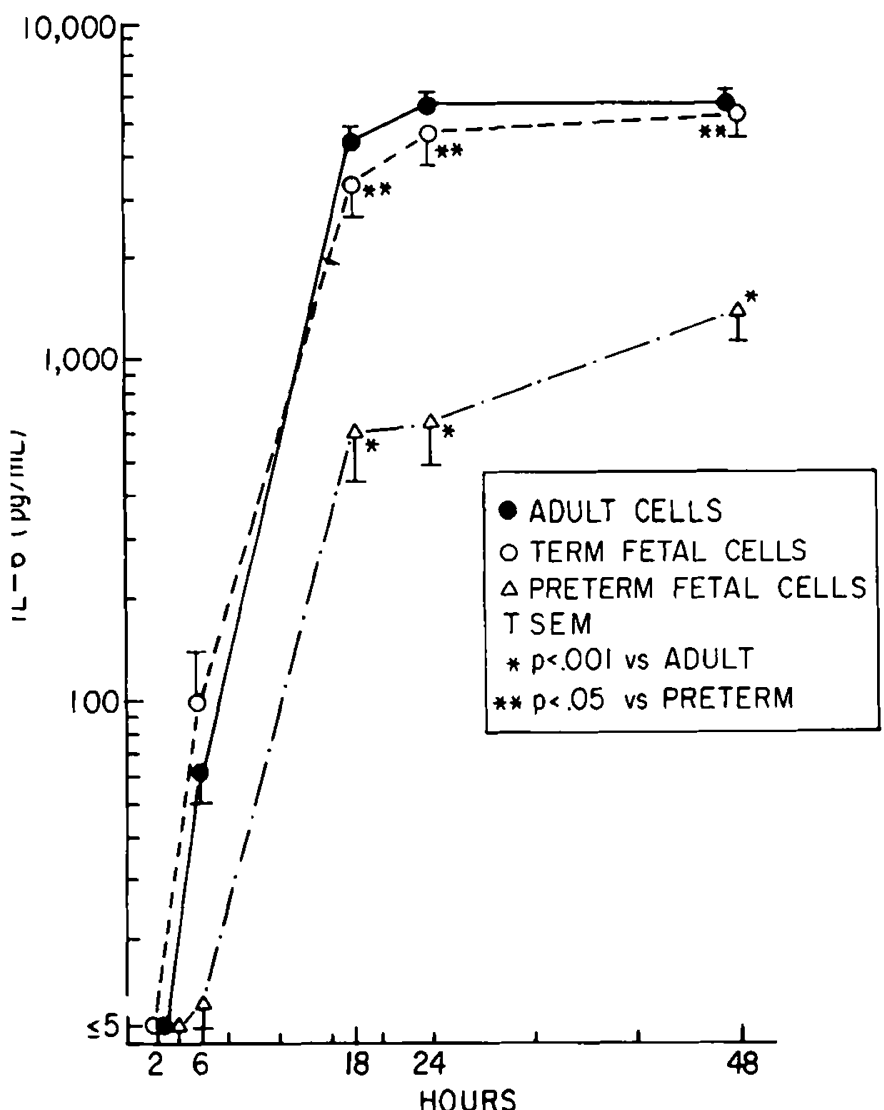

Fig. 2. Interleukin-6 concentrations were determined in supernatants at various intervals after stimulating mononuclear cells obtained from he blood of adults, term neonates, and preterm neonates with IL-1.

were similar in supernatants of adult and term cells after 18,24 , and $48 \mathrm{~h}$ of culture. Concentrations in supernatants from preterm sells, however, were consistently lower than in those from adult and term neonatal cells.

Accumulation of IL- 6 mRNA by circulating mononuclear cells rom adults, term neonates, and preterm neonates is shown in Figure 3. Before incubation with IL-1 $\left(\mathrm{T}_{0}\right)$, little or no IL-6 nRNA was detected in cells from adult (lane 1), term (lane 5), or preterm (lane 9) subjects. However, after a 24-h incubation with IL-1, IL-6 mRNA was detected in cells from all three adults lanes 2-4), whereas less was detected in cells from the three erm neonates (lanes 6-8). IL-6 mRNA was detected in cells of unly one (lane 10) of the three preterm neonates (lanes 10-12). The proportion of monocytes in the preparations of light-density :ells from adults $(12.0 \pm 8.3 \%$, mean, $\pm S D)$ did not differ from hat of the neonates $(15.7 \pm 6.1 \%)$.

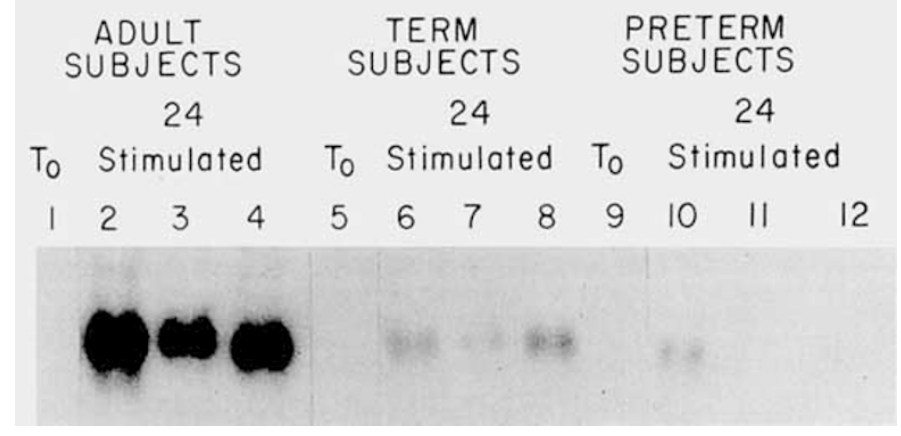

Fig. 3. IL-6 mRNA accumulation by blood mononuclear cells obtained from three adults, three term neonates, and three preterm neonates. IL-6 mRNA was determined before $\left(T_{0}\right)$ and $24 \mathrm{~h}$ after incubation

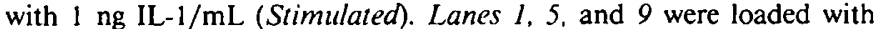
RNA extracted from blood mononuclear cells of adult, term, and preterm origin, respectively, before stimulation with IL-1. Lanes 2,3 , and 4 were loaded with RNA from blood mononuclear cells of three adults $24 \mathrm{~h}$ after stimulation with IL-1. Lanes 6, 7, and 8 were loaded with RNA from blood mononuclear cells of three term neonates $24 \mathrm{~h}$ after stimulation with IL-1, and lanes 10, 11 , and 12 were loaded with RNA from blood mononuclear cells of three preterm neonates $24 \mathrm{~h}$ after stimulation with IL-1.

\section{DISCUSSION}

Preterm labor is often the result of intraamniotic infection (15 ), but the mechanism by which infection induces the onset of labor is not known. It has been speculated that infection leads to an increased generation of prostaglandins that initiate labor (5). Prostaglandin biosynthesis during intraamniotic infection might be the result of bacterial phospholipase (21) or actions of cytokines produced by macrophages or amnion cells (22-24).

Rapid diagnosis of intraamniotic bacterial infection in women with preterm labor can be important to the medical management of the pregnancy. Despite its importance, however, the diagnosis of infection in its early stages is often difficult. In our study, we sought to determine whether concentrations of IL-6, a cytokine with a central role in antibacterial defense, were higher in amniotic fluid of women with preterm labor associated with intraamniotic infection than in fluid from women in preterm labor without intraamniotic infection. Indeed, IL-6 concentrations in fluid from which organisms were recovered were significantly greater than in culture-negative fluid. It is not clear whether the one culture-negative case with elevated amniotic fluid IL-6 (Fig. 1) had an undetected infection or whether stimuli other than microbes initiated IL-6 production.

During intraamniotic infection, maternal and fetal macrophages can be present in amniotic fluid (25). Because a variety of cells, including monocytes and macrophages, produce IL-6 after stimulation $(26,27)$, we postulated that the high IL-6 concentrations in infected amniotic fluid might have been produced from either maternal or fetal cells, or a combination of the two. The likelihood that fetal cells produce IL- 6 during intraamniotic infection could not be assessed empirically, because production of IL- 6 by human fetal cells had not previously been reported. Therefore, we obtained fetal and maternal cells, and after stimulation by IL-1, directly compared production of IL-6. IL-6 was detected in supernatants from umbilical venous endothelial cells, fetal blood mononuclear cells, decidua, and maternal blood mononuclear cells.

In other studies, we compared IL- 6 accumulation in cultures of a standardized number of mononuclear cells obtained from the blood of healthy adults and from term and preterm infants. No substantial differences were observed in the kinetics of IL-6 accumulation in cultures of adult and term neonatal cells. In contrast, substantially less IL-6 was present in supernatants of cells from preterm neonates. Our studies do not determine whether this was the result of less IL- 6 accumulation by the same 
number of participating cells, reduced populations of IL-6 producing cells, or increased binding or degradation of IL- 6 by preterm cells. However, we favor the hypothesis that less IL-6 was produced by cells of preterm neonates because we observed far less IL-6 mRNA in extracts from such cells (Fig. 3).

In our studies, we also observed less IL-6 mRNA accumulation after stimulation with IL-1 in mononuclear cells from term neonates than in those from adults. It is not clear why IL-6 generation by cells from term neonates was only slightly less than that by cells from adults (Fig. 2), whereas their IL-6 mRNA accumulation was substantially less (Fig. 3). Cellular accumulation of IL-6 mRNA is the net result of transduction of signals for production, the transcription rate, message stability, and efficiency of translation. Clearly, additional investigation will be required to determine the explanation for reduced mRNA, but similar IL- 6 concentrations, in the term neonatal cells versus adult cells.

We emphasize that our study did not attempt to establish the utility of IL-6 quantification as a means of rapidly diagnosing intraamniotic infection. Similarly, a recent report by Romero $e t$ al. (28), in which high IL-6 concentrations were observed in infected amniotic fluid, did not evaluate the diagnostic or prognostic usefulness of IL-6 determination in the management of women in preterm labor. Rather, the purposes of our studies were, first, to test the hypothesis that IL- 6 concentrations in amniotic fluid would be increased during intraamniotic infection and, second, to assess the capacity of a variety of fetal and maternal cells to generate IL- 6 in vitro. Indeed, whether quantification of IL-6 in amniotic fluid would be of clinical utility remains to be determined.

Finally, we point out that limitations in antibody production $(29,30)$ and neutrophil production $(31,32)$ have been described in preterm neonates. It has been suggested that such limitations might, in part, be responsible for the increased susceptibility of preterm neonates to overwhelming bacterial infection (33). Because IL- 6 appears to play a regulatory role in antibody production (10-12) and granulocytopoiesis (13-16), reduced IL-6 production by cells of preterm neonates might be relevant to the understanding of their limitations in antibacterial defense.

\section{REFERENCES}

1. Garite TJ, Freeman RK 1982 Chorioamnionitis in the preterm gestation. Obstet Gynecol 59:539-545

2. Zlatnick FJ, Cruikshank DP, Petzold CR 1984 Amniocentesis in the identification of inapparent infection in preterm patients with premature rupture of the membranes. J. Reprod Med 29:656-660

3. Lamont RF, Taylor RD, Wigglesworth JS, Furr PM, Evans RT, Elder MG 1987 The role of mycoplasmas, ureaplasmas, and chlamydiae in the genital tract of women presenting in spontaneous early preterm labour. J Med Microbiol 24:253-257

4. Pritchard JA, MacDonald PC, Gant NF 1985 Preterm and Postterm Pregnancies and Fetal Growth Retardation. In: Pritchard JA, MacDonald PC, Gant NF (eds) Williams Obstetrics, 17th Ed. Appleton-Century-Crofts, Norwalk, CT, pp 750-751

5. Romero R, Mazor M 1988 Infection and preterm labor. Clin Obstet Gynecol 31:544-555

6. Romero R, Emamian M, Quintero R, Wan M, Hobbins J, Mazor M, Edberg S 1988 The value and limitations of the Gram stain examination in the diagnosis of intraamniotic infection. Am J Obstet Gynecol 159:114-119
7. Taddonio TE, Thomson PD, Tait MJ, Prasad JK, Feller I 1988 Rapid quantification of bacterial and fungal growth in burn wounds: biopsy homogenate Gram stain versus microbial culture results. Burns Incl Therm Inj 14:180184

8. Marsh JC, Boggs DR, Cartwright GE, Wintrobe MM 1967 Neutrophil kinetics in acute infection. J Clin Invest 46:1943-1953

9. Rosenberg HS 1987 Cardiovascular effects of congenital infections. Am J Cardiovasc Pathol 1:147-156

10. Kishimoto T 1989 The biology of interleukin-6. Blood 74:1-10

11. Takatsuki F, Okano A, Suzuki C, Chieda R, Takahara Y, Hirano $\Upsilon$, Kishimoto $T$, Hamuro $H$, Akiyama Y 1988 Human recombinant interleukin-6/B-cell stimulatory factor-2 (IL-6/BSF-2) augments murine antigen-specific antibody responses in vitro and in vivo. J Immunol 141:3072-3077

12. Lotz M, Jirik F, Kabouridis R, Tsoukas C, Hirano T, Kishimoto T, Carson DA 1988 BSF-2/IL-6 is costimulant for human thymocytes and $T$ lymphocytes. J Exp Med 167:1253-1258

13. Ikebuchi K, Wong GG, Clark SC, Ihle JN, Hirai Y, Ogawa M 1987 Interleukin6 enhancement of interleukin-3-dependent proliferation of multipotential hemopoietic progenitors. Proc Nat. Acad Sci USA 84:9035-9039

14. Leary AG, Ikebuchi K, Hirar Y, Wong GG, Yang Y-C, Clark SC, Ogawa M 1988 Synergism between interleukin- 6 and interleukin- 3 in supporting proliferation of human hemopoietic stem cells: Comparison with interleukin-1 alpha. Blood 71:1759-1763

15. Gardner JD, Liechty KW, Christensen RD 1990 Effects of interleukin-6 on fetal hematopoietic progenitors. Blood 75:2150-2155

16. Liechty KW, Christensen RD 1990 In vivo effect of interleukin-6 on cycling status of hematopoietic progenitors from adults and neonates. Pediatr Res 28:323-326

17. Delvin EE, Arabian A, Glorieux FH, Mamer OA 1985 In vitro metabolism of 25-hydroxycholecalciferol by isolated cells from human decidua. J Clin Endocrinol Metab 60:880-885

18. Jaffe EA, Nachman RL, Becker CG, Minick CR 1973 Culture of human endothelial cells derived from umbilical veins. J Clin Invest 52:2745-2756

19. Sambrook J, Fritsch EF, Maniatas T 1989 Molecular Cloning: A Laboratory Manual. Cold Spring Harbor Laboratory Press, Cold Spring Harbor, New York

20. Church GM, Gilbert W 1984 Genomic sequencing. Proc Natl Acad Sci USA 81:1991-1995

21. Bejar R, Curbelo V, Davis C, Gluck L 1981 Premature labor. II. Bacterial sources of phospholipases. Obstet Gynecol 57:479-482

22. Romero R, Hobbins JC, Mitchell MD 1988 Endotoxin stimulates prostagliadin E2 release from human amnion. Obstet Gynecol 71:227-228

23. Romero R, Durum S, Dinarello CA, Hobbins JC, Mitchell MD 1989 Interleukin-1 stimulates prostaglandin biosynthesis by human amnion. Prostaglandins 37:13-22

24. Lamont RF, Rose M, Elder MG 1985 Effects of bacterial products on prostaglandin E production by amnion cells. Lancet 2:1 1 $31-1133$

25. Keenan WJ, Steichen JJ, Mahmood K, Altshuler G 1977 Placental pathology compared with clinical outcome. Am J Dis Child 131:1224-1228

26. De Man P, Van Kooten C, Aarden L, Engberg I, Linder H, Svanborg Eden C 1989 Interleukin- 6 induced at mucosal surfaces by Gram-negative bacterial infection. Infect Immun 57:3383-3388

27. Sironi M, Breviario F, Proserpio P, Biondi A, Vecchi A, Van Damme J, DeJanna E, Mantovani A 1989 IL-I stimulates IL-6 production in endothelial cells. J Immunol 142:549-553

28. Romero R, Avila C, Santhaman U, Sehgal PB 1990 Amniotic fluid interleukin6 in preterm labor. $J$ Clin Invest 85:1392-1400

29. Wilson CB 1986 Immunologic basis for increased susceptibility of the neonate to infection. J Pediatr 108:1-12

30. McCracken Jr GH, Eichenwald HF 1971 Leukocyte function and the development of opsonic and complement function in the neonate. Am $J$ Dis Child 121:120-126

31. Cairo MS 1987 Granulocyte transfusions in neonates with presumed sepsis. Pediatrics 80:738-740

32. Koenig JM, Christensen RD 1989 Incidence, neutrophil kinetics, and natural history of neonatal neutropenia associated with maternal hypertension. $\mathrm{N}$ Engl J Med 21:556-562

33. Siegle JD, McCracken Jr GH 1981 Sepsis neonatorum. N Engl J Med 304:642647 